\title{
鉛塩注射による硬組織内時刻描記法を応用した 歯槽骨の修復過程に関する研究
}

\author{
小林英和宮下元 \\ 遠 藤 信 武横田誠 \\ 東京医科歯科大学第 2 歯科保存学教室（主任指導 : 木下四郎教授）
}

（昭和47年10月16日受付）

Repair Following Periodontal Osseous Surgery according to
the labeling with lead acetate

Hidekazu Kobayashi, Hajime Miyashita, Nobutake Endo, Makoto Yokota

Dept. of Periodontology, School of Dentistry,

Tokyo Medical and Dental University

(Chief director: Prof. Shiro Kinoshita)

要旨 : 歯槽骨自体に標識をつけて歯槽骨の修復状態を経時的に把握する手段として, 岡田, 三村による酢 酸鉛法1) が応用できるか，また応用する場合の問題点を明らかにする目的で， 5 頭の雑犬の 犬歯煩側歯槽骨 を用いて実験を行なった。犬歯煩側の歯槽骨頂を一辺とする $3 \mathrm{~mm}$ の正方形の歯槽骨をノミで切除し, 削除 断端の歯にノミでノッチをつけて, 酢酸鉛法を応用して手術後の歯槽骨修復状態の 経時的な变化を比較検討 した。

酢酸鉛の注射によって得られる鉛線は術後 1 週間目頃より歯槽骨頂に出現し，術後 2 週間目には明瞭な黒 紫色の線（金鍍金による）としてみえるようになった。しかし術後 1 週と 2 週に静注した鉛塩の，沈着線は分 離しておらず，この間における歯槽骨頂の骨形成はほとんど進行していなかったことが示された。

術後 $1 ， 2 ， 8$ 週間目（56日目）飞鉛塩を静注し，8週間目（57日目）に屠殺したものでは，新生骨表層 に鉛線が出現し，8 週間目の鉛線と，ほとんど蒾槽骨頂でかさなっている術後 1,2 週の線との間隔がひろ くなり,この間にかなりの骨新生がみられた。術後 8 週間目の鉛線は歯槽骨削除断端の標識として歯につけ たノッチまで修復していた。

サルと犬の歯間部歯槽骨に水平性，二壁性，三壁性骨欠損をつくって鉛線の標識をした所見を観察できた。 酢酸带鉛でも酢酸鉛と同様に歯槽骨の修復過程を観察することが可能であり，鉛線と識別可能な沈着線と して新生骨組織に沈着することがわかった。

\section{I. はじめに}

歯周疾患には歯槽骨のいろいろな形状の退縮が おこる。このような歯槽骨について様々な研究が 行なわれており, 外科的療法後の歯槽骨の修復に



報告5) 9) 10) がある。

外科的に骨削除を行なつた後, 歯肉弁の再付着 や歯槽骨の修復などに関する研究として歯にノッ チをつける方法を応用した報告は Stones ${ }^{2)}$ (1934) 以来, Linghorne ${ }^{3)}$ (1950), Morris ${ }^{4)}$ (1953), 伊 藤 $^{5)}$ (1953), 柳田 ${ }^{6)}$ (1958), Marfino ${ }^{7)}$ (1959), 
小林 ${ }^{8)}$ (1971) らによるものがある。

またこの修復状態を計測しょうとする試みも近 年臨床的に行われており, 最近では Wood ${ }^{9 /}(1972)$ らが Full Thickness Flaps と Partial Thickness Flaps のそれぞれについて，煩側の歯槽骨頂の減 少值をノギスで測定している。

また Osseous Surgery 後の骨については Wil$\operatorname{derman}^{10)}$ (1970) らがノミで歯につけたノッチ を基準点としている。これらの実験は計測しやす い煩側の歯槽骨について行なわれているが，ノミ でノッチをつける方法は比較的，正確に手術時の 歯槽骨を描記できその後の修復過程に障害となり にくい利点があると考えられる。

しかし，臨床上，多椂な骨久損の形態を示す歯 間部歯槽骨についての修復過程を追跡するために は，ノミによるノッチ記録法を用いる事ができ ず，今まで行なわれて来た ${ }^{2 / 8}$ ように歯科用バー によるノッチにたよるらざるをえなかった。その 場合には，前回，著者 ${ }^{8}$ が行なった実験でも指 摘したように，骨の修復過程に不利な状態とな ることもあり，またノミによるノッチにくらべ て, 歯科用バーのノッチはやや不正確な場合があ つた。

そこで今回の実験で，著者らは歯槽骨自体に標 識をつけて，歯槽骨の修復状態を把握したいと思 い，岡田，三村の鉛塩注射 ${ }^{111}$ による硬組織内時 刻描記法の応用について検討し，またこれを歯槽 骨の修復過程に応用する場合の問題点を明らかに する目的で以下に述べる実験を行なった。

\section{II. 実験方法}

永久歯萠出の完成した成雑犬 5 頭を用いた。手 術部位は犬歯煩側の歯槽骨とした。手術に先だつ て Nembthal $30 \mathrm{mg} / \mathrm{kg}$ を後肢静脈より注入し 全身麻酔を施し，手術部位に 局所麻酔剂（2\%キ シロカイン， $1 / 8$ 万エピレナミン含有） $2 \mathrm{cc}$ を行 なった。犬歯の近心，遠心の歯肉に縦切開を入 れ，歯軸にほぼ平行にメスを当て歯肉辺縁に歯槽 骨頂に達する切開を施した後, 歯肉弁を剝離した。 図 1 に示すような正方形の骨欠損を刀幅 $3 \mathrm{~mm}$ の

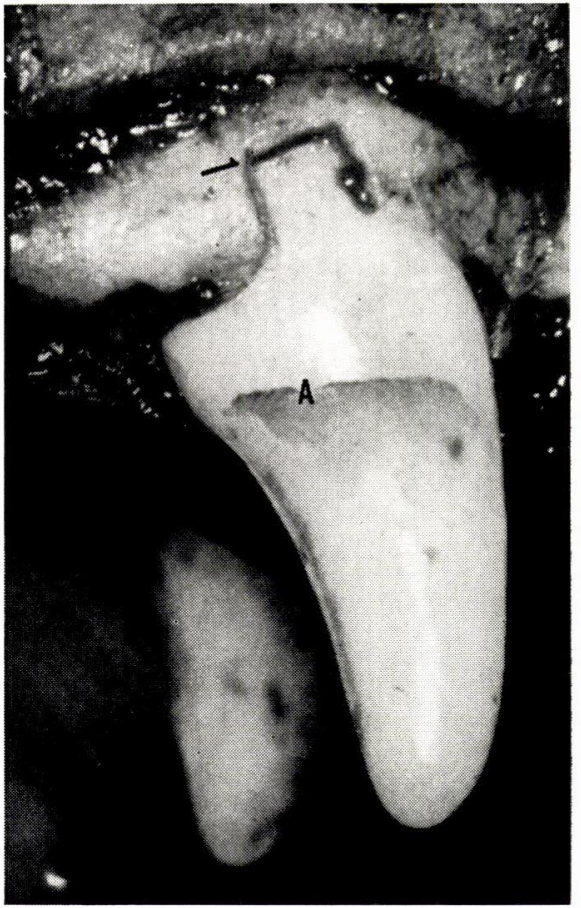

闵 1 歯肉弁を剥離して歯槽骨を露出させ，ノミで $3 \mathrm{~mm}$ 平方の骨欠損をつくり，矢印 $(\rightarrow)$ の削 除断端にノミでノッチをつけた。Aは辺縁歯 肉頂が歯に接していた位置である。

鋭利な骨ノミにより歯槽骨に形成し，歯槽骨削除 底には同一のノミによりノッチを歯牙に形成し歯 槽骨断端の標識とした。歯根面を平滑にして，歯 肉弁を元に戻どして犬歯の近，遠心の歯問部と縦 切開線中央で縫合した。食物は通常の固形飼料を あたえ，一週間目に抜糸をして，表1のような各 時期の歯槽骨形成状態が観察できるように酷酸鉛 を $5 \mathrm{mg} / \mathrm{kg}$ 静注した。酢酸亜鉛 ${ }^{11}(5 \mathrm{mg} / \mathrm{kg})$ 法 1 の中で「ア」と記してある時期の歯槽骨形成状 態が観察できるように静注を行なった。犬は表 1 にあるような各時期に屠殺し，犬歯を含む顎骨を 1 つのブロツクとし, 常法 ${ }^{1)}$ に従がって 標本を作 製した。標本は煩舌側方向 $15 \mu$ で薄切し， $0.1 \%$ 塩化金で金鍍金を行ない検鏡した。

また歯問部歯槽骨にいろいろな形の骨欠損をつ くった場合の鉛線の標識について，著者 ${ }^{8)}$ の 1 人

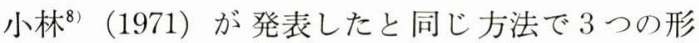


表 1 手術後の経過時間と鉛塩沈着線の観察部位

\begin{tabular}{|c|c|c|c|c|c|c|}
\hline 週犬 & No. 1 & No. 2 & No. 3 & \multicolumn{2}{|c|}{ No. 4} & No. 5 \\
\hline 0 & LR & LL & & UL & & \\
\hline 1 & LL & UR & UR LR & LR & UR & UR LL \\
\hline 2 & UL & & & & & $\mathrm{UR}_{T} \mathrm{LL}_{T}$ \\
\hline 3 & & & $\mathrm{UR}_{\Gamma} \mathrm{LR}_{T}$ & & & \\
\hline 4 & & UR & & & & \\
\hline 5 & & & & & UR & \\
\hline 6 & & & & & & \\
\hline 7 & & & & & & \\
\hline 8 & & & & & & UR LL \\
\hline & $\begin{array}{l}\vdots \text { 下顎 } \\
\vdots \text { 下顎 } \\
\text { 酢酸 }\end{array}$ & $\begin{array}{l}\text { UR } \\
\text { UL } \\
\xi の\}\end{array}$ & $\begin{array}{c}\text { 上顎右側 } \\
\text { 上䓏左側 } \\
\text { 酷酸鉛 }\end{array}$ & 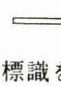 & 屠 & した日 \\
\hline
\end{tabular}

の骨久損（水平性骨欠損，二壁性骨久損，三壁性 骨欠損）をつくった後，酢酸鉛を注射し，歯間部 の歯槽骨にどのような線として出現するものかし らべるため, Bohen による推定年令で $4 \sim 6$ 歳の カニクイザル 3 例, 成雑犬 3 例に㧍こなった。常 法 ${ }^{1)}$ に従がって標本を作製した。標本は近遠心方 向 $15 \mu$ で薄切し， $0.1 \%$ 塩化金で 金鍍金を行ない 検鏡した。

\section{III. 結果と考按}

肉眼でみた 治恶状態は各時期とも非常に良好 で，災症状態も少なかった。術後 4 週目頃に，炎 症のいくぶん強くなる犬もあったが，術後 6 週目 では，どの犬もほとんど変化がなく，歯肉縁の退 縮もごくわずかであった。

煩舌側方向に 薄切し， $0.1 \%$ 塩化金鍍金後の結 果は次のようであった。

鉛線は図 5 に示すように手術直後に静注しても 歯槽骨断端には認められなかった。

術後 1 週間目に䣷酸鉛を静注したものは，図 6 のように鉛線が歯槽骨断端に認められた。しかし， 歯槽骨断端附近の鉛線は，その後の鉛線にくらべ 一般にうすく，所々乱れている場合が多かった。

黒須 ${ }^{12)}$ (1960) は生活歯髄切断法に抢ける庇蓋 組織の形成においても，手術後10日以後にならな いと鉛線がはっきりと見えにくいと述べている



図 2 術後 1 週間目。治癒良好であった。



四 3 術後 4 週間目, やや発赤が辺縁にのこり, 腫 脹もみられる。

が，歯槽骨の場合はこれよりもやや早い時期に鉛 線が出現するようである。

術後 2 週間目に䣷酸鉛を静注したものでは図 7 のように明瞭に鉛線が歯槽骨外形にそって出現し た。 


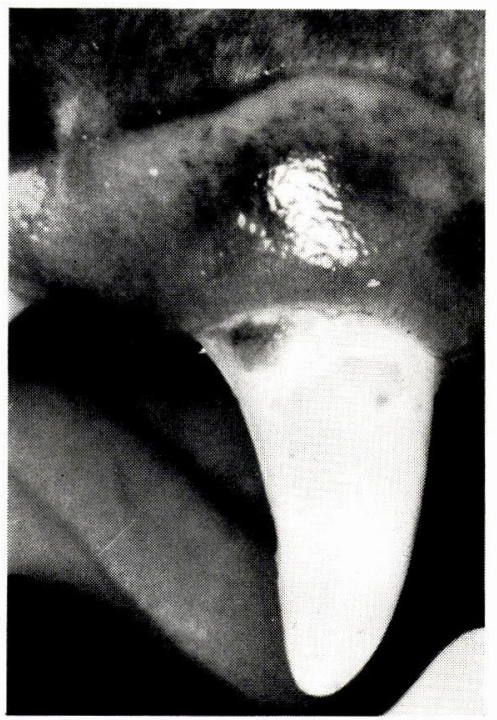

困 4 術後 6 週間目, 発赤も腫脹もなくなり術前の 状態に近くなった。

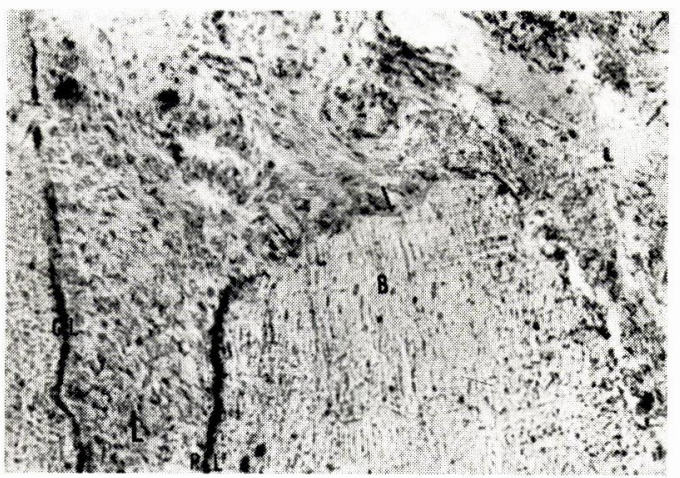

図 5 術直後に酢酸鉛を注射した場合に，歯槽骨断 端（ (）には鉛線が認められない。CL はセ メ ト質表層，PL は歯根膜側の歯槽骨表層 の鉛線であろ。L汇歯根膜。Bは歯槽骨。標 本の薄切は煩舌方向である。（原倍率100倍）

術後 1 週間目に酢酸鉛を, 3 週間目に酢酸覀鉛 を静注したものでは，図 8 のように，鉛線と亜鉛 線がほとんどかさなって表われた。しかし図 9 の ように，歯根膜側の歯槽骨の部分と図 8 の煩側歯 槽骨の一部に 2 本の 線が分離してみえたものもあ った。図 9 は骨欠損を行なっていない部分の標本 で，図 8 と同じ歯の標本である。煩側歯槽骨の表 面は一度吸収された後, 再び修復が行なわれた状 態が示されたている。Wood ${ }^{9)}$ (1972) らは臨床的

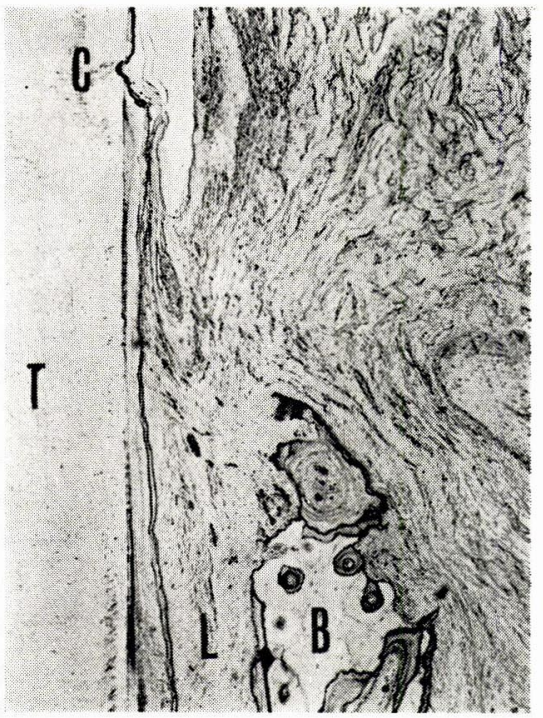

四 6 術後 1 週間目に酢酸鉛を注射したもので，歯 槽骨頂に鉛線がみられる。Cはノッチ，Tは 歯 (象牙質)，Bは歯槽骨， L は歯根膜。(原 倍率50倍)。

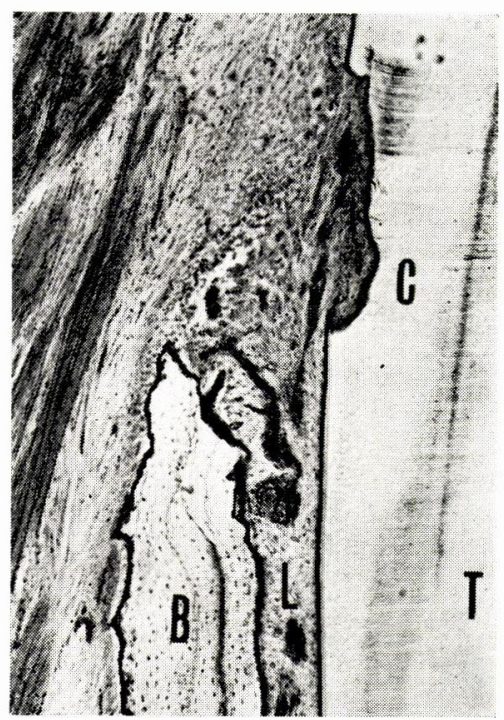

図 7 術後 2 週間目に酢酸鉛の注射をしたもので, 明瞭な鉛線が歯槽骨頂に出現している。C は ノッチ, B は歯槽骨, Lは歯根膜。 Tは歯 (象牙質)，(原倍率50倍)

に Full Thicknes Flaps のみで $0.62 \mathrm{~mm}$ の歯槽 骨頂の退縮がおこることを観察している。

次に術後 1 週間目に酢酸鉛を， 2 週間目に酢酸 


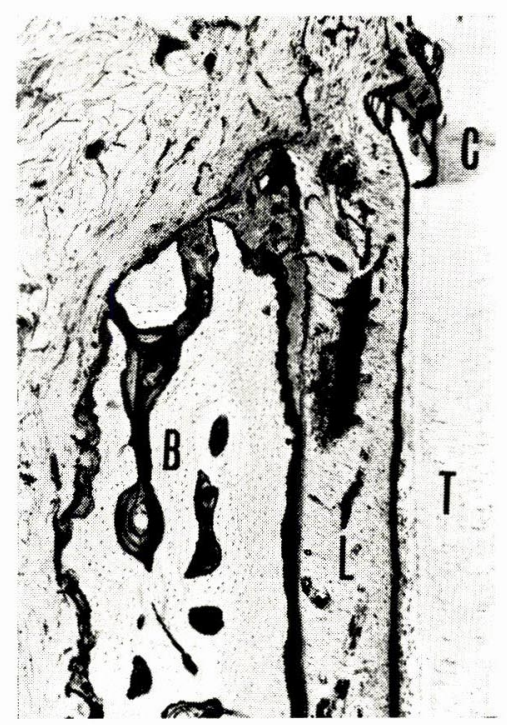

図 8 術後 1 週間目に酢酸鉛を，術後 3 週間目に酢 酸亜鉛を注射したもの。歯槽骨頂では一本の 線として認められる。Cはノッチ, Bは歯槽骨, $\mathrm{L}$ 注歯根膜， T歯(象牙質)。(原倍率50倍)。

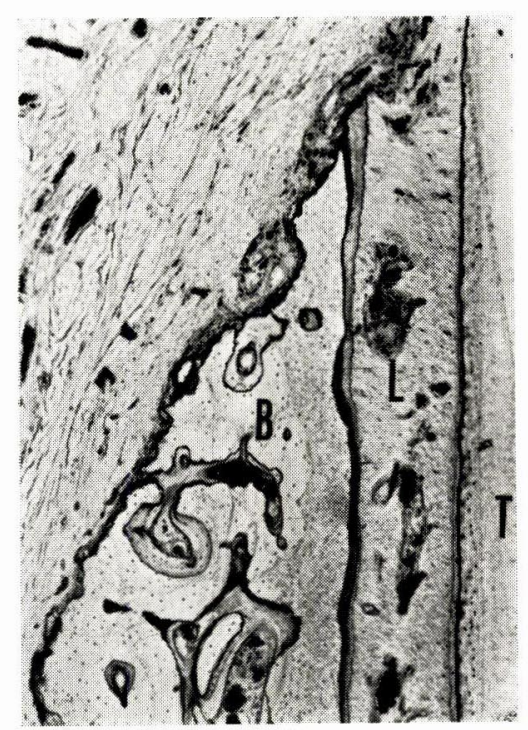

図 9 図 8 と同じ標本で骨削除を行なっていない部 位。歯根膜側の歯槽骨に 2 本の線がみられ る。術後に扔ける煩側歯槽骨表面の複雑な修 復状態が鉛線によって示されている。Bは歯 槽骨, Lは歯根膜, Tは歯 (象牙質)。(原倍 率50倍)

亜鉛を，8週間目（56日目）に酢酸鉛を各々静注 して 8 週間目（57日目）に屠殺した場合の鉛線や



図 10 術後 1 週間目に酢酸鉛 $\left(\mathrm{L}_{1}\right)$, 術後 2 週間目 江䣷酸要鉛 $\left(\mathrm{L}_{2}\right)$, 術後 8 週間目に酷酸鉛 ( $\left.\mathrm{L}_{8}\right)$ を注射した。 $\mathrm{L}_{1}$ と $\mathrm{L}_{2}$ はほとんどか さなっているが歯根膜側で一部, 分離して いる所もある。B注歯槽骨， Lは歯根膜， Tは歯 (象牙質)，Cはノッチ。(原倍率50倍)

亜鉛線の状態を図10に示す。

歯槽骨縁に一本のよく染まる鉛線が認的られ る。これは術後 8 週間目に静注した鉛線であろ う。この線は歯につけたノッチとほぼ同じ高さに あった。この線の内側で,ッチより約 $1.25 \mathrm{~mm}$ 根 尖には赤紫色に染まる亜鉛線と，黒紫色に染まる 鉛線が大部分かさなって濃く染まる線が見えた。 これらの事からすると，歯槽骨は術後，削除断端 より約 $1.25 \mathrm{~mm}$ ほど退縮し，ほぼ 1 週間目頃より 修復が始まり，歯槽骨の厚みを増すが，術後 2 週 目では，歯槽骨頂部の歯冠方向への増加はほとん どなく, 術後 8 週間目に，ほぼ歯槽骨削除断端の 標織として歯につけたノッチまで回復したものと 考えられる。

Wilderman $^{10)}$ (1970) らは Osseous Surgery 後の骨の修復を臨床的に観察している。それによ ると手術 1,2 週間目に平均 $1.2 \mathrm{~mm}$ の骨の吸収 があり，その後 3 週から18力月後に平均 $0.4 \mathrm{~mm}$ の骨が形成されるが，結局，平均 $0.8 \mathrm{~mm}$ の減少 として治瘉するとしている，今回の実験では 8 週 
間目にすでに骨が削除断端の高さまで 回復してい るのは，骨久損の形がちがい，今回の欠損が修復 しやすい形だったためであろらと考えられる。

次に歯間部歯槽骨にいろいわな 形の骨欠損をつ くった場合の鉛線の標識についてのべる。

著者の一人，小林 ${ }^{8)}$ (1971) が発表したと 同じ 方法で 3 つの形の骨欠損（水平性骨欠損，二壁性 骨欠損，三壁性骨欠損）をつくった後，酢酸鉛を 注射し，歯間部の歯槽骨にどのような線として 出現するものかをしらべるため，サル 3 例，犬 3 例におこなった。その主な所見は次のようであっ た。

サルの前歯部に水平性骨欠損をつくり術後51週 間目に酢酸鉛を静注し，54週間目に屠殺した。そ の結果，図11のように歯槽骨頂に明瞭な一本の鉛 線が骨外形よりやや内側に認められ，また歯根膜 に接する歯槽骨にそって，根尖方向にも鉛線が出 現していた。

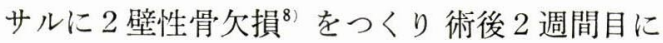
酢酸鉛を静注し，その後，4週間目に屠殺したも



困 11 サルの前歯部に水平欠損をつくっで ${ }^{8)}$, 術 後51週間目に酢酸鉛を注射し，術後54週間 経過した歯間部歯槽骨を示す。歯槽骨頂に 1 本の鉛線が骨外形よりやや内側にみえる。 Tは歯(象牙質)， B は歯槽骨，Cはノッ千。 (原倍率30倍)。

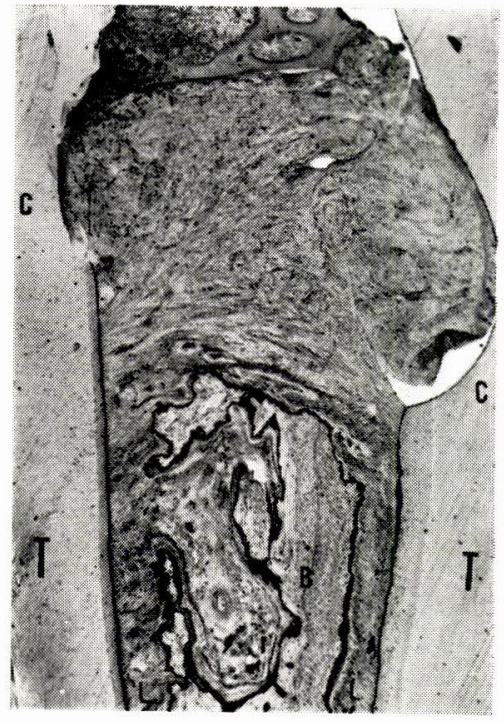

図 12 サルに 2 壁性骨欠損8) をつくり，術後 2 週 間目に酢酸鉛を注射し，その後 4 週間経過 した歯間部歯槽骨を示す。C は歯科用バー でつけたノッチ。Tは歯 (象牙質), Bは歯 槽骨。(原倍率40倍)。

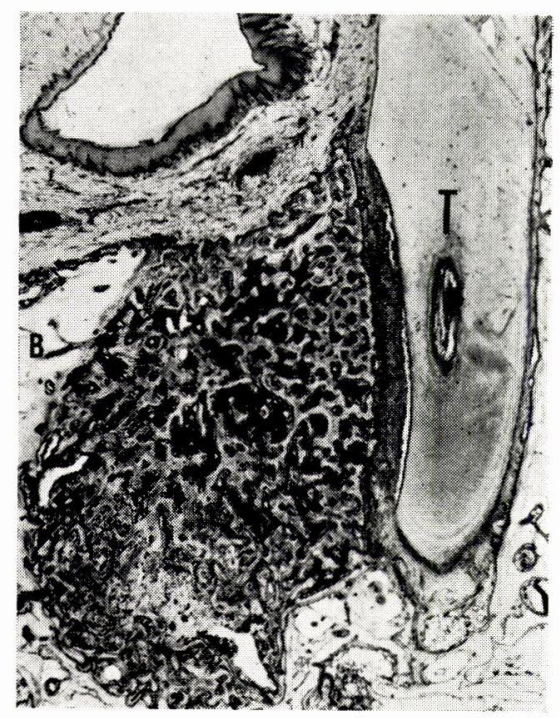

図 13 犬に 3 壁性骨欠損をつくり，5週間目に酢 酸鉛を注射し，その後 1 週間経過したとき の状態。新生骨小梁中に鉛線がみえる。T は歯, B歯槽骨。(原倍率15倍)。

のでは, 困120よらに，歯槽骨頂に酢酸鉛静注後 できた類骨様組織が歯冠方向にのびだしていた。 犬に 3 壁性骨欠損 ${ }^{8)}$ をつくり 5 週間目に酢酸鉛 
を静注し，その後 1 週間目に屠殺したものでは図 13のように新生骨小梁中，全体に鉛線がうすく沈 着していた。歯科用バーによって歯の象牙質まで も削除してしまったが，歯と新生骨との間には幅 の広い歯根膜が存在していた。

以上の実験結果から 推察して歯槽骨自体に時刻 描記線を入れて歯槽骨の修復状態を把握しょ5と する時には，次のような実験計画がその一つとし て考えられる。

まず術後 2 週間目に䣷酸鉛を注射し，この時点 で歯につ訬たノッチから 2 週間目の鉛線（I とす る）までの距離を側定して，信頼できる值（ $\mathrm{R}$ と する）をもとめる（今回は $\mathrm{R} の$ 值を得るに適当な 例数ではなかったので, 今後例数を増やして実験 を行なっていかなければならないが，本実験例の 結果ではほぼ1.2mm 前後の值が多かった)。

次に知ろうとする修復日時に酢酸鉛（II とする） を静注し，鉛塩が歯槽骨に沈着するに必要な時間 をまって，(布施 ${ }^{13)}$ (1958) らは注射後30分以内に して現在石灰化しつつある骨の部分に 鉛が沈着す るといる。）動物を屠殺し，常法"1) こごとく標本 を作製する。標本上で 2 本の鉛線間の 距離（Ｉ～ II）から Rを引いた值が 歯槽骨削除断端からの歯 槽骨の修復值となるわけである。その結果がプラ スならば歯槽骨は削除位置より歯冠側に伸だした わけであり，マイナスならば削除位置より根尖に 退縮したわけである。

また今回，酢酸鉛とともに酢酸亚鉛を用いた結 果, 塩化金で鍍金すると赤紫色を呈する亜鉛線が みられた。これは黒紫色の鉛線とは区別すること ができ，酢酸亜鉛も歯槽骨時刻描記法に使用でき る可能性が示された。

なお手術直後から 2 週間のあいだのどの時点か ら歯槽骨頂に明瞭な鉛塩の 沈着が始まるかについ ては,さらに短かい時間間隔で鉛塩の静注を行な ってその時期を知ることが必要であろう。鉛塩は 硬組織の石灰化が起っている 部位に沈着するとい われているので, 手術後, 鉛沈着線が観察され始 める最短時期を明らかにすることは，骨の修復が 開始される時期を知るらえでも重要だと考えられ
る。実験の結果からその時期が 1 调間前後である ことは確実であるから先に実験結果からの考擦で 述べた静注時期の 2 週間より多少早くなるものと 考えられる。今後この点について検索を進め, 鉛 塩注射による硬組織内時刻描記法を歯槽骨の修復 過程の研究に応用する方法を具体化して行く予定 である。

\section{IV. 結 論}

歯槽骨自体に標識をつけて 歯槽骨の修復状態を 時問的に把握したいと思い，岡田，三村による酢 酸鉛法が応用できるか，またこれを応用する場 合の問題点を知る目的で， 5 頭の成雑犬を用い, 犬歯煩側歯槽骨にノミで $3 \mathrm{~mm}$ の正方形の骨欠損 をつくり，酢酸鉛法によりその修復過程を観察し た。

1）手術直後に酢酸鉛を静注しても，歯槽骨断 端には鉛線が認められなかった。

2）手術後 1 週間目に酢酸鉛を 静注すると, 歯 槽骨削除断端にも 鉛線がみとめられた。しかしこ の鉛線はその後の新生骨組織に沈着した 鉛線にく らべるとうすく，所々乱れている場合が多かった。

3）手術後 2 週間目， 3 週間目に酢酸鉛を静注 すると，歯槽骨削除断端にも鉛線が明瞭にみとめ られた。

4）削除した歯槽骨の修復は次のようであつ た。手術後，歯槽骨は削除断端より約 $1.2 \mathrm{~mm}$ ほ ど吸収され，ほぼ 1 週間目頃より修復が起り始め る。。術後 2 週間目までは，歯槽骨の歯冠方向一 の増加はほとんどなく，歯槽骨の厚みだけが増加 して行く像を認めた。けれども術後 8 週間目には ほぼ歯槽骨削除断端の 標識としたノッチまで修復 した。

5）サルと犬の歯間部歯槽骨に水平性，二壁 性，三壁性骨欠損をつくつて鉛線の標識をした所 見についてのべた。

6）酢酸亜鉛でも酢酸鉛と同様に歯槽骨の修復 過程を観察することが可能であり，鉛線と識別可 能な沈着線として 新生骨組織に沈着することが示 された。 


\section{謝辞}

稿を終わるにあたり，終始，御指導と御校閲を賜わっ た当教室主任木下四郎教授はじめ, 歯科薬理学小椋秀亮 教授, 硬研薬理学麻生田亮教授, 難聴研病理秋吉正豊教 授, 口腔病理学小守昭助教授, 岩手医科大学第二歯科保 存学上野和之助教授に衰心より感謝を捧げます。また種 種御助力, 御鞭撻下さった当教室岩見一男先生, 芳賀健 輔先生ならびに当教室員各位に心からの謝意を表しま す。

本論文の要旨の一部は，1971年 9 月 25 日第14回日本歯 周病学会において発表した。

\section{参考文献}

1）小椋秀亮：鉛塩注射による硬組織の生体染色， 歯界展望， $35: 893 ， 1970$.

2) Stones, H. H. : The Reaction and Regeneration of Cenentum in Various Pathological Condition, Proc. Roy. Soc. Med., $27: 728$, 1934.

3) Linghorne, W. J. \& O'Connell, D. C. : Studies in the Reattachment and Regeneration of the Supporting Structures of the Teeth. I. Soft Tissue Reattachment., J. Dent. Res., $29: 419,1950$.

4) Morris, M. L.: The Reattachment of $\mathrm{Hu}$ man Periodonal Tissues Following Surgical
Detachment: A Clinical and Histological Study., J. Periodont. 24 : 220, 1953.

5）伊藤秀夫：改良歯肉剝離掻爬手術について. 実 験的並に臨床的研究，口科誌， $5: 438 ， 1956$.

6) 柳田藤吉, 土谷裕彦：失活歯の歯肉剥離創の治 癒に関する実験的研究, 口科誌, $7: 235,1958$.

7) Marfino, N. R., Orban, B. J. \& Wentz, F. M. : Repair of the Dento-Gingival Junction Following Surgical Intervention., J. Periodont., $30: 180,1959$.

8）小林英和 : サルの歯槽骨にいろいろな欠損を与 えた場合の修復過程について，口病誌，38:404， 1971.

9) Wood, D. L.. Hoag, P. M., Donnenfeld, O. W., Resenfeld, L. D. : Alveolar Crest Reduction Following Full and Partial Thickness Flaps., J. Periodont., 43 : 141, 1972.

10) Wilderman, M. N., Pennel, B. M., King, K., Barron, J. M. : Histogenesis of Repair Following Osseous Surgery., J. Periodont., $41: 551,1970$.

11) 麻生田亮 : 硬組織における重金属塩の沈着機構 に関する研究, お茶の水医学雑誌, 8: 510, 1960.

12）黒須一夫 : 水酸化カルシウム覆罩による生活歯 髄切断法における庇蓋硬組織の形成機序に関す る研究, 口病誌, $25: 55,1960$.

13）布施貞夫，松田登：酢酸鉛による硬組織の生体 染色法（その 1 )，歯界展望，15:297，1958. 